\title{
Effect Invesment and The Rate of Inflation to Economic Growth in Indonesia
}

\author{
Saparuddin M. \\ Fakultas Ekonomi Universitas Negeri Jakarta \\ Jl. Rawamaangun Muka No. 1 Jakarta Timur \\ E-Mail: itunk77@gmail.com \\ Selly Yolanda \\ Karuniana Dianta A. Sebayang \\ Fakultas Ekonomi Universitas Negeri Jakarta \\ Jl. Rawamaangun Muka No. 1 Jakarta Timur
}

\begin{abstract}
This study aims is to determine the influence of investment and the rate of inflation either partially or simultaneously to economic growth in Indonesia. This research was conducted in Indonesia using data quarterly for 9 years from 2005 to 2013. Types of data used are secondary data. The research method is using time series multiple regression method. The regression results showed that investment and inflation partially and simultaneosly has positive and significant effect on economic growth in Indonesia.
\end{abstract}

Keywords: economic growth, investment, rate of inflation.

\begin{abstract}
ABSTRAK
Penelitian ini bertujuan untuk mengetahui pengaruh investasi dan tingkat inflasi baik secara parsial maupun simultan terhadap pertumbuhan ekonomi di Indonesia. Penelitian ini dilakukan di Indonesia dengan menggunakan data sekunder runtut waktu kuartalan dari tahun 2005 sampai 2013. Metode penelitian bersifat kuantitatif dengan analisis model menggunakan analisis regresi berganda. Hasil penelitian menunjukkan bahwa investasi secara parsial berpengaruh positif dan signifikan terhadap pertumbuhan ekonomi, dan inflasi secara parsial berpengaruh negatif signifikan terhadap pertumbuhan ekonomi di Indonesia.
\end{abstract}

Kata Kunci: pertumbuhan ekonomi, investasi, tingkat inflasi. 


\section{PENDAHULUAN}

Pembangunan ekonomi pada hakikatnya merupakan serangkaian usaha dan kebijaksanaan yang bertujuan untuk meningkatkan taraf hidup masyarakat, memperluas lapangan kerja, pemerataan pembagian pendapatan masyarakat, dan mengusahakan pergeseran aktivitas ekonomi dari sektor berbasis pertanian menuju sektor industri. Salah satu yang menjadi tolak ukur penting dalam menentukan pencapaian pembangunan ekonomi adalah pertumbuhan ekonomi yang menggambarkan suatu dampak riil dari kebijakan pembangunan yang telah dilaksanakan. Pertumbuhan ekonomi itu sendiri terkait dengan proses peningkatan hasil produksi barang dan jasa dalam kegiatan ekonomi masyarakat. Untuk mengetahui pertumbuhan ekonomi suatu negara dapat dilihat melalui Produk Domestik Bruto (PDB).

Pertumbuhan ekonomi dicerminkan dari adanya perubahan PDB dari satu periode ke periode berikutnya, yang merupakan salah satu petunjuk nyata pembangunan, baik secara langsung maupun tidak langsung merupakan keberhasilan implementasi kebijakan. Seperti diketahui, pertumbuhan ekonomi diartikan sebagai suatu proses pertumbuhan output perkapita dalam jangka panjang. Hal ini berarti, bahwa dalam jangka panjang, kesejahteraan tercermin pada peningkatan output perkapita yang sekaligus memberikan banyak alternatif dalam mengkonsumsi barang dan jasa, serta diikuti oleh daya beli masyarakat yang semakin meningkat.
Secara garis besar, perekonomian Indonesia sangat ditentukan oleh tingkat keberhasilan Pemerintah dan Bank Sentral dalam menjaga stabilitas makro serta keberhasilan dalam implementasi reformasi struktural dan peningkatan kapasitas kelembagaan, serta didukung oleh efek positif dari sisi eksternal dalam menghadapi tantangan dunia. Grafik persentase pertumbuhan ekonomi yang ditunjukkan dengan PDB berdasarkan harga konstan tahun 2005-2013 dapat dilihat pada Gambar 1.

Grafik tersebut menunjukkan pertumbuhan ekonomi yang fluktuatif. Terlihat pada tahun 2005 pertumbuhan mencapai 5,69\% dari tahun sebelumnya. Kemudian terjadi penurunan pertumbuhan pada tahun berikutnya yaitu tahun 2006 dan 2007. Pada tahun 2008 pertumbuhan ekonomi kembali naik sebesar 6,01, hingga terjadi kenaikan dan penurunan pada tahun-tahun berikutnya. Dalam jangka pendek, berlanjutnya ketidakpastian di pasar keuangan dan perekonomian global yaitu meningkatnya tekanan inflasi dan melambatnya pertumbuhan ekonomi global, pertumbuhan ekonomi Indonesia akan ditentukan oleh keberhasilan kebijakan ekonomi makro (kebijakan fiskal dan moneter) untuk mengendalikan stabilitas makro tanpa mengorbankan pertumbuhan ekonomi. Sementara dalam jangka menengah panjang lima tahun kedepan, pergerakan perekonomian Indonesia akan lebih ditentukan oleh faktor-faktor yang menggerakkan perekonomian dalam jangka panjang, seperti investasi, sumber daya manusia, dan produktivitas/efisiensi.

Pertumbuhan Ekonomi (dalam persen) 2005-2013

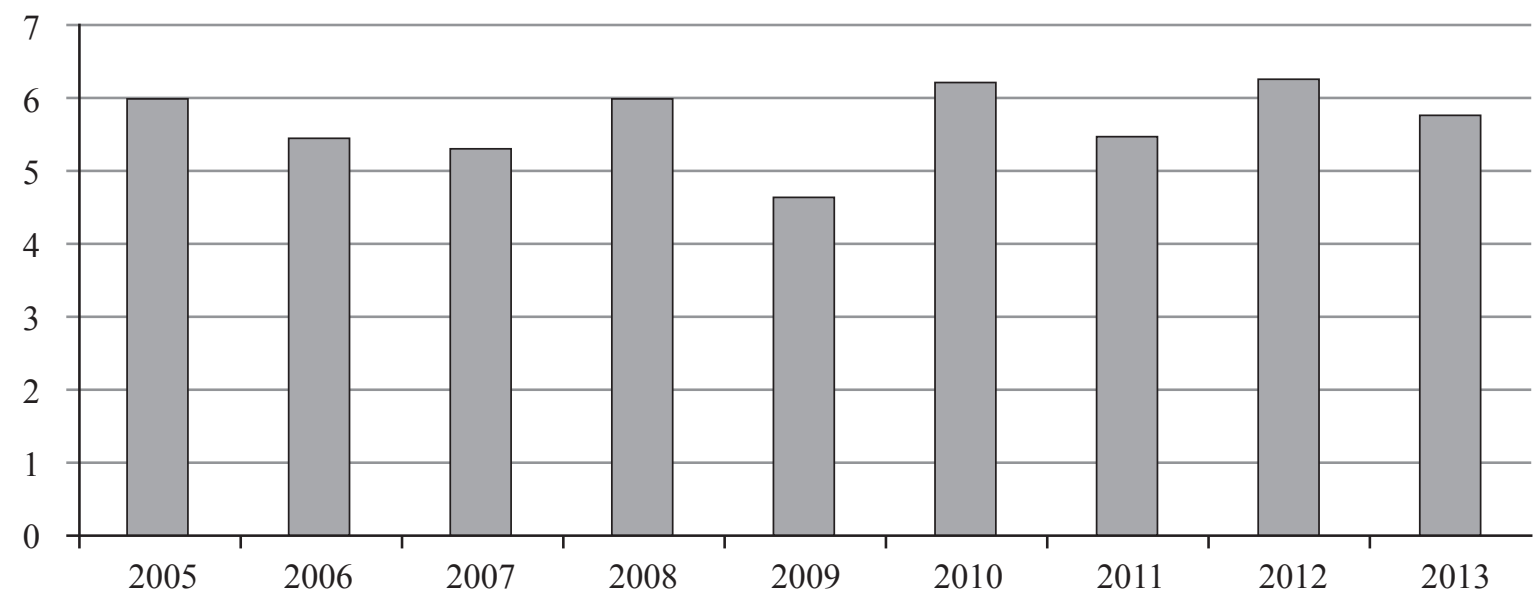

Sumber: BPS (diolah)

Gambar 1. Pertumbuhan Ekonomi

(PDB harga konstan) (\%) 
Dari sisi produksi, implementasi reformasi struktural diasumsikan berjalan baik sehingga produktivitas tenaga kerja, penguasaan teknologi, dan modal fisik akan cenderung meningkat serta distribusi akan menjadi lebih efektif. Keempat faktor ini akan bersifat jangka panjang dalam mendorong Total Factor Productivity (TFP) sehingga perusahaan mampu menghasilkan output yang lebih tinggi. Selain itu, berbagai faktor tersebut akan meningkatkan efisiensi perusahaan untuk melakukan proses produksi yang menyebabkan marginal cost akan cenderung menurun dan akan menekan tambahan biaya akibat distribusi yang semakin efektif.

Kondisi tersebut akan menyebabkan menurunnya ongkos produksi dan harga jual sehingga inflasi dalam jangka panjang terdorong turun. Namun di sisi lain, dari sisi eksternal, kecenderungan tingginya harga komoditas minyak dan pangan dunia akan menyebabkan marginal cost meningkat karena adanya tambahan biaya untuk melakukan proses produksi. Namun demikian, penurunan marginal cost akibat adanya efisiensi diperkirakan masih lebih besar dari pada kenaikan marginal cost akibat tekanan dari sisi eksternal tersebut sehingga dalam jangka panjang, inflasi yang cenderung turun menuju targetnya.

Penurunan inflasi tersebut sejalan dengan upaya Bank Indonesia untuk secara konsisten menerapkan Inflation Targeting Framework (ITF) pada tahun 2000 yang terintegrasi dalam serangkaian kebijakan makro ekonomi dan sektoral. Dalam hal ini, penetapan BI Rate senantiasa konsisten dengan pencapaian target inflasi, namun dengan tidak menghambat pencapaian pertumbuhan ekonomi yang tinggi dan berkualitas.

Sejalan dengan menurunnya inflasi dalam jangka menengah 2010-2013, Bank Indonesia akan mulai menurunkan tingkat BI Rate secara gradual. Sinergi antara komitmen Pemerintah dan Bank Indonesia dalam menjaga stabilitas ekonomi makro selain memberi dampak positif terhadap sisi penawaran, juga memberi dampak positif terhadap sisi permintaan.
Grafik tingkat inflasi tahun 2005 hingga 2013 dapat dilihat pada Gambar 2.

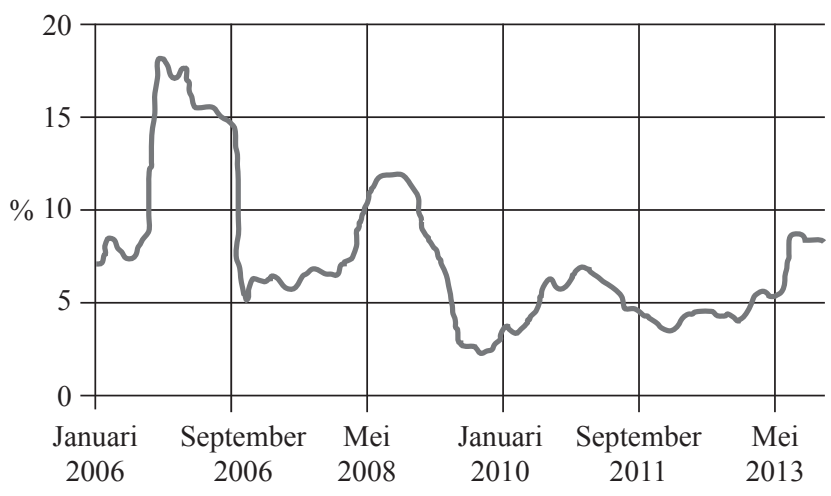

Sumber: Bank Indonesia_(www.bi.go.id)

Gambar 2. Grafik tingkat inflasi tahun 2005 hingga 2013

Gambar 2. memperlihatkan tingkat inflasi dari tahun ke tahun mengalami fluktuatif (naikturun). Fenomena fluktuatif tersebut disebabkan oleh beberapa hal, antara lain dampak kenaikan harga minyak dunia pada tahun 2005, krisis global yang terjadi pada tahun 2008, serta dampak dari diselenggarakannya pemilu pada tahun 2009. Halhal yang terjadi tersebut menuntut pemerintah untuk membuat suatu sinergi dari kebijakan baik secara fiskal maupun moneter, guna menstabilkan perekonomian. Dengan adanya sinergi tersebut, baik kebijakan fiskal maupun kebijakan moneter akan lebih efektif dalam mempengaruhi sisi demand melalui konsumsi, investasi, maupun pengeluaran pemerintah secara langsung, seperti yang terlihat pada Tabel 1 .

Sementara itu, dengan perkiraan menurunnya inflasi dalam jangka menengah-panjang akibat semakin meningkatnya kredibilitas Bank Indonesia dan rendahnya ekspektasi inflasi pelaku pasar yang berimplikasi pada rendahnya tingkat bunga riil, maka investasi meningkat sekitar $12,5 \%-13,9 \%$ pada tahun 2013.

Tabel 1. Proyeksi Perekonomian Indonesia 2008-2013 (dalam persen)

\begin{tabular}{|c|c|c|c|c|c|c|c|c|c|c|c|c|}
\hline \multirow{2}{*}{$\begin{array}{l}\text { Proyeksi Pertumbuhan PDB } \\
\text { Konsumsi (\%) }\end{array}$} & \multicolumn{2}{|c|}{2008} & \multicolumn{2}{|c|}{2009} & \multicolumn{2}{|c|}{2010} & \multicolumn{2}{|c|}{2011} & \multicolumn{2}{|c|}{2012} & \multicolumn{2}{|c|}{2013} \\
\hline & 5,1 & $-5,6$ & 5,2 & $-5,9$ & 5,2 & $-5,6$ & 5,4 & $-5,8$ & 5,6 & $-6,0$ & 5,7 & $-6,1$ \\
\hline Konsumsi Pemerintah (\%) & 5,8 & $-6,3$ & 12,5 & $-13,5$ & 5,3 & $-5,7$ & 5,5 & $-5,9$ & 5,7 & $-6,1$ & 5,9 & $-6,3$ \\
\hline Investasi (\%) & 12,7 & $-13,2$ & 13,6 & $-14,6$ & 10,5 & $-12,0$ & 11,0 & $-12,5$ & 12,0 & $-13,5$ & 12,5 & $-13,9$ \\
\hline Ekspor barang dan jasa (\%) & 14,6 & $-15,1$ & 9,1 & $-10,1$ & 10,7 & $-11,3$ & 11,3 & $-11,7$ & 11,7 & $-12,3$ & 12,2 & $-12,6$ \\
\hline Impor barang dan jasa (\%) & 16,3 & $-16,8$ & 16,4 & $-17,4$ & 13,7 & $-14,1$ & 14,3 & $-14,7$ & 15,1 & $-15,5$ & 15,8 & $-16,2$ \\
\hline
\end{tabular}

Sumber: Badan Pusat Statistik (diolah) 
Dengan adanya dorongan dari sisi konsumsi dan investasi tersebut perekonomian akan tumbuh tinggi sehingga mendorong pendapatan pemerintah (pajak dan penerimaan bukan pajak) yang selanjutnya digunakan untukmembiayai pengeluaran pemerintah yang tumbuh sekitar 5,9\% - 6,3\% pada tahun 2013 dengan asumsi pemerintah tetap memberikan stimulus fiskal dengan tetap memperhatikan kesinambungan fiskalnya. Sementara itu, daya saing yang meningkat serta membaiknya permintaan dunia berdampak pada tetap tingginya kinerja ekspor.

Untuk Indonesia, keberhasilan implementasi paket stimulus fiskal yang berspektrum jangka pendek terkait dengan upaya pencegahan dan penanganan dampak krisis, juga menjadi pijakan yang sangat penting dan menentukan keberhasilan program perbaikan ekonomi dalam jangka menengah. Sejalan dengan skenario perbaikan ekonomi global tersebut, kinerja ekspor pada tahun 2010 kembali mengalami penguatan. Pada periode selanjutnya penguatan kinerja ekspor diperkirakan akan semakin mantap, yang didukung oleh semakin membaiknya daya saing sebagai hasil dari implementasi berbagai perbaikan struktural yang secara konsisten dilaksanakan oleh pemerintah.

Pertumbuhan ekonomi Indonesia mencapai di atas $6 \%$ per tahun pada 2013 , didukung oleh permintaan domestik yang tinggi. Bank Dunia memproyeksikan PDB Indonesia tumbuh 6,2\% tahun berikutnya dan tetap optimis dengan prospeknya meski ada ketidakpastian global. Lembaga lain seperti IMF juga memprediksikan pertumbuhan di kisaran $6 \%$.

Faktor lain yang mempengaruhi pertumbuhan ekonomi yaitu Investasi (akumulasi modal) meliputi semua investasi baik investasi yang dilakukan oleh pemerintah maupun pihak swasta. Investasi yang ditanamkan dapat berbentuk tanah, peralatan fisik, dan modal atau sumber daya manusia. Dengan demikian investasi pada hakekatnya juga merupakan langkah awal dalam kegiatan pembangunan ekonomi. Investasi akan terjadi jika ada bagian dari pendapatan sekarang yang ditabung dan kemudian diinvestasikan untuk memperbesar output pada masa yang akan datang.

Kegiatan investasi memungkinkan masyarakat untuk terus-menerus meningkatkan kegiatan ekonomi yang dapat meningkatkan pendapatan nasional dan taraf kemakmuran. Adanya investasi baru memungkinkan terciptanya barang modal baru sehingga akan menyerap faktor produksi seperti tenaga kerja. Dengan demikian terjadi penambahan output nasional. Kekurangan modal yang disebabkan oleh rendahnya investasi terutama investasi langsung dalam proses ekonomi di negara berkembang menyebabkan negara tersebut tetap miskin.

Investasi langsung (direct invesment) khususnya foreign direct investment (FDI) memiliki efek positif bagi pembangunan ekonomi suatu negara. Dampak positif FDI di antaranya adalah peningkatan produktivitas, transfer teknologi, pengenalan proses-proses produksi terkini, peningkatan kemampuan manajerial, pengenalan pasar domestik lebih baik, pelatihan tenaga kerja, peningkatan jaringan produksi internasional, dan peningkatan akses pasar internasional. Untuk negara-negara berkembang, FDI juga dipandang sebagai faktor alternatif untuk meningkatkan aliran modal masuk ke dalam negeri (Effendi dan Soemantri, 2003). Seberapa besar dampak investasi asing langsung terhadap pertumbuhan ekonomi suatu negara akan berbeda-beda satu dengan lainnya. Perbedaan ini tergantung dari berbagai karakteristik sosial ekonomi negara yang menjadi penerima investasi (Nunnenkamp dan Spatz, 2004).

\section{METODE}

Metode penelitian yang digunakan dalam penelitian ini adalah metode Ex Post Facto. Ex Post Facto adalah suatu penelitian yang dilakukan untuk meneliti peristiwa yang telah terjadi dan kemudian merunut ke belakang untuk mengetahui faktor-faktor yang dapat menyebabkan timbulnya kejadian tersebut. Sesuai dengan tujuan penelitian yaitu untuk mengetahui apakah terdapat pengaruh antara investasi dengan pertumbuhan ekonomi di Indonesia dan untuk mengetahui apakah terdapat pengaruh antara tingkat inflasi dengan pertumbuhan ekonomi di Indonesia.

Model analisis yang digunakan dalam penelitian ini adalah regresi linier berganda dengan metode OLS (Ordinary Last Square). Regresi ini bertujuan untuk mengetahui pengaruh kuantitatif antara variabel-variabel yang diteliti yaitu pertumbuhan ekonomi sebagai variabel terikat, investasi sebagai variabel bebas pertama, dan inflasi sebagai variabel bebas kedua. 
Tabel 2. Oprasionalisasi Variabel Penelitian

\begin{tabular}{|c|c|c|}
\hline Variabel & Definisi Konseptual & Definisi Operasionalisasi \\
\hline $\begin{array}{l}\text { Pertumbuhan } \\
\text { Ekonomi }\end{array}$ & $\begin{array}{l}\text { Pertumbuhan ekonomi adalah suatu keadaan di mana } \\
\text { terjadi kenaikankapasitas produksi (output) dalam } \\
\text { perekonomian yang dipengaruhi oleh perubahan barang } \\
\text { modal, tenaga kerja, teknologi, manajemen dan lainnya } \\
\text { yang diukur untuk mengetahui pembangunan ekonomi } \\
\text { suatu negara. }\end{array}$ & $\begin{array}{l}\text { Pertumbuhan ekonomi suatu negara } \\
\text { dapat dilihat dari Produk DomestikBruto } \\
\text { sebagai total produksi (output) yang } \\
\text { dihasilkan oleh suatu negara pada suatu } \\
\text { periode. Pada penelitian ini menggunakan } \\
\text { data berdasarkan harga konstan. }\end{array}$ \\
\hline Investasi & $\begin{array}{l}\text { Investasi dapat diartikan sebagai pengeluaran atau } \\
\text { penanaman modal atau perusahaan untuk membeli barang- } \\
\text { barang modal dan perlengkapan-perlengkapan produksi } \\
\text { untuk menambah kemampuan memproduksi barang- } \\
\text { barang dan jasa-jasa yang tersedia dalam perekonomian } \\
\text { dan diharapkan mampu memberikan keuntungan yang } \\
\text { maksimal di masa mendatang.Investasi dapat berasal dari } \\
\text { dalam negeri (PMDN) maupun dari luar negeri (PMA). }\end{array}$ & $\begin{array}{l}\text { Investasi dalam penelitian ini diperoleh } \\
\text { dari laporan yang ada di Badan Koordinasi } \\
\text { Penanaman Modal (BKPM) mengenai } \\
\text { Realisasi Penanaman Modal baik berasal } \\
\text { dari dalam negeri (PMDN) maupun dari } \\
\text { luar negeri (PMA) di Indonesia. }\end{array}$ \\
\hline Tingkat Inflasi & $\begin{array}{l}\text { Tingkat inflasi merupakan suatu kondisi pada saat terjadi } \\
\text { kenaikan harga secara umum yang berlangsung secara } \\
\text { terus-menerus pada perekonomian suatu negara, di } \\
\text { mana terjadi penurunan nilai mata uang sehingga dapat } \\
\text { menurunkan daya beli masyarakat dan merusak stabilitas } \\
\text { perekonomian suatu negara. }\end{array}$ & $\begin{array}{l}\text { Tingkat inflasi adalah tingkatan } \\
\text { persentase kenaikan harga-harga di } \\
\text { masyarakat. }\end{array}$ \\
\hline
\end{tabular}

Metode ini dipilih karena sesuai dengan tujuan penelitian yang ingin dicapai, yaitu untuk menerapkan kaitan antara variabel-variabel yang diteliti. Penelitian ini untuk menguji pertumbuhan ekonomi (dilihat dari PDB harga konstan) yang dipengaruhi oleh investasi dan tingkat inflasi.

Data yang digunakan dalam penelitian adalah data sekunder. Data skunder merupakan data dalam bentuk yang sudah jadi atau berupa data publikasi. Data tersebut mengenai jumlah Produk Domestik Bruto (berdasarkan harga konstan), investasi, dan tingkat inflasi. Data yang digunakan adalah data pertriwulan, maka objek berjumlah 36, diperoleh dari Januari 2005 sampai Desember 2013. Sumber data diperoleh dari Badan Pusat Statistik (BPS), Badan Koordinasi Penanaman Modal (BKPM), dan Bank Indonesia (BI).

\section{Operasionalisasi Variabel}

Operasionalisasi variabel dimaksudkan untuk mengetahui pengaruh pengukuran variabelvariabel penelitian. Operasionalisasi variabel untuk menentukan jenis indikator, serta skala dan variabel-variabel yang terkait (Tabel 2).

\section{Model Penelitian}

Rumus Regresi Linear ganda yaitu untuk mengetahui pengaruh secara kuantitatif adanya konvergensi konidisional dari investasi (X1), dan inflasi (X2) terhadap pertumbuhan ekonomi (Y) di mana fungsinya dapat dinyatakan dalam bentuk persamaan:

$\Delta[\log \mathrm{Y}]=\mathrm{a}+\mathrm{b}_{1} \log \mathrm{X}_{1}+\mathrm{b}_{2} \log \mathrm{X}_{2}+\mathrm{b}_{3} \log _{\mathrm{Yt}-1}+\varepsilon$ di mana $\Delta[\log \mathrm{Y}]=\log \mathrm{Y}_{\mathrm{t}}-\log \mathrm{Y}_{\mathrm{t}-1}$

Keterangan:

Y : Pertumbuhan Ekonomi

$\mathrm{X}_{1} \quad$ : Investasi

$\mathrm{X}_{2} \quad$ : Tingkat inflasi)

$\mathrm{Y}_{\mathrm{t}-1}$ : PDB tahun sebelumnya

$\mathrm{b}_{1}, \mathrm{~b}_{2}$ : Koefisien korelasi

$\begin{array}{ll}\text { a } & : \text { Konstanta } \\ \varepsilon & : \text { Error term }\end{array}$

\section{HASIL}

Regresi linear berganda dilakukan untuk mengetahui hubungan kuantitatif antara variabel dependen (pertumbuhan ekonomi) dan variabel 
independen (investasi dan tingkat inflasi) di Indonesia. Berdasarkan data yang diolah dengan menggunakan metode regresi berganda maka diperoleh hasil sebagai berikut.

\section{Uji Koefisien Regresi}

Uji koefisien regresi dilakukan dengan membandingkan $\mathrm{T}_{\text {hitung }}$ dengan $\mathrm{T}_{\text {tabel }}$ dari kolom $\mathrm{t}$ di dalam coefficients table pada output SPSS, dapat dilihat pada Tabel 3.

Tabel 3. Coefficients Table

\begin{tabular}{|c|c|c|c|c|c|c|}
\hline & \multirow[b]{2}{*}{ Model } & \multicolumn{2}{|c|}{$\begin{array}{l}\text { Unstandardized } \\
\text { Coefficients }\end{array}$} & \multirow{2}{*}{$\begin{array}{c}\begin{array}{c}\text { Standardized } \\
\text { Coefficients }\end{array} \\
\text { Beta }\end{array}$} & & \multirow[b]{2}{*}{ Sig. } \\
\hline & & B & Std. Error & & & \\
\hline \multirow[t]{3}{*}{1} & (Constant) & 1,847 & 1,860 & & 993 & ,354 \\
\hline & Investasi & ,923 & 390 & 706 & 2,368 & ,050 \\
\hline & Inflasi &,- 094 & 246 &,- 114 &,- 381 & ,714 \\
\hline
\end{tabular}

Dari Tabel 3. terlihat $\mathrm{T}_{\text {sig }}$ untuk variabel investasi pada taraf signifikan 0,05 dengan $\mathrm{T}(0.05,34)$ diperoleh $\mathrm{T}_{\text {tabel }}$ sebesar 2,028 , jadi 2,368 $>2,028$ berarti Ho ditolak maka menunjukan bahwa investasi berpengaruh positif dan secara nominal signifikan terhadap pertumbuhan ekonomi.

Untuk variabel inflasi, diperoleh nilai $\mathrm{T}_{\text {hitung }}$ sebesar -0,381, pada taraf signifikan 0,05 dengan $\mathrm{T}(0.05,34)$ diperoleh $\mathrm{T}_{\text {tabel }}$ sebesar 2,028. Oleh karena $-0,381<2,028$ berarti Ho diterima, artinya menunjukan bahwa inflasi secara nominal tidak signifikan dan berpengaruh negatif terhadap pertumbuhan ekonomi.

\section{Koefisien Determinasi}

Koefisien determinasi dapat dilihat dari model summary table pada output SPSS dengan melihat nilai R square (Tabel 3).

Tabel 3. Summary Table

\begin{tabular}{lcc}
\hline Model & $\mathrm{R}$ & R Square \\
\hline 1 &, $674^{\mathrm{a}}$ &, 455 \\
\hline
\end{tabular}

Dari hasil output SPSS diperoleh angka R2 sebesar 0,455. Hal ini menunjukkan bahwa variasi sumbangan pengaruh variabel independen (investasi dan tingkat inflasi) adalah tinggi. Hal ini berarti sebanyak $45,5 \%$ variasi pertumbuhan ekonomi dapat dijelaskan oleh perubahan atau variasi dari investasi dan tingkat inflasi, sedangkan sisanya sebesar 54,5\% dipengaruhi faktor lain.

\section{PEMBAHASAN}

Berdasarkan hasil regresi, dapat dianalisis bagaimana hubungan antara pertumbuhan ekonomi dengan inflasi dan investasi berdasarkan kajian teoritis dan hasil-hasil penelitian sejenis lainnya.

\section{Investasi}

Sesuai dengan hasil pengujian hipotesis yang menggunakan uji menunjukkan bahwa investasi secara parsial signifikan dan berpengaruh positif terhadap pertumbuhan ekonomi. Nilai koefisien regresi untuk variabel investasi sebesar 0,923. Tanda positif mengindikasikan bahwa pengaruh investasi terhadap pertumbuhan ekonomi adalah positif. Arti dari nilai koefisien regresi tersebut adalah jika variabel independen lain nilainya tetap dan variabel investasi (X1) mengalami kenaikan sebesar 1\% maka pertumbuhan ekonomi (Y) akan mengalami kenaikan sebesar $0,923 \%$.

Secara teori pengaruh investasi yang positif dan signifikan terhadap pertumbuhan ekonomi dapat dijelaskan oleh teori pertumbuhan ekonomi HarrodDomar yang menjelaskan bahwa investasi akan menyebabkan pertumbuhan ekonomi meningkat. Teori Harrod-Domar memberikan peranan kunci kepada investasi dalam pertumbuhan ekonomi. Investasi berpengaruh terhadap permintaan agregat, yaitu melalui penciptaan pendapatan dan terhadap penawaran agregat melalui peningkatan kapasitas produksi. Dengan adanya peningkatan jumlah investasi akan menyebabkan peningkatan produktivitas produksi yakni dengan bertambahnya lapangan kerja (usaha), jumlah modal produksi, serta penyerapan tenaga kerja.

Berdasarkan hasil penelitian, didapatkan fakta yang sama. Pengaruh positif investasi akan meningkatkan pertumbuhan ekonomi di mana investasi dapat meningkatkan pertumbuhan ekonomi yang didapat melalui peningkatan output dari adanya investasi tersebut.

Dari persamaan pendapatan nasional secara makro, $\mathrm{Y}=\mathrm{C}+\mathrm{I}+\mathrm{G}+\mathrm{X}-\mathrm{M}$, di mana $\mathrm{Y}=$ pendapatan nasional (PDB). Dapat diketahui bahwa 
investasi (I) merupakan salah satu komponen pembentuk PDB. Jika investasi meningkat maka PDB juga akan meningkat. Peningkatan PDB menunjukkan peningkatan ekonomi atau secara umum dikenal sebagai pertumbuhan ekonomi.

Untuk meningkatkan laju pertumbuhan ekonomi suatu negara, selain melalui usaha peningkatan sumber pembiayaan dalam negeri, tetap dibutuhkan sumber pembiayaan luar negeri. Perlunya peningkatan investasi diharapkan dapat memacu pertumbuhan ekonomi, kesejahteraan masyarakat, meningkatkan peran aktif masyarakat, serta memperluas kesempatan usaha dan lapangan kerja. Untuk mencapai targettarget tersebut diperlukan usaha penciptaan iklim investasi yang menarik sehingga dapat menarik investor (penanam modal), menjamin kepastian usaha serta keamanan investasi.

Hasil penelitian sebelumnya menunjukkan bahwa investasi, baik dalam bentuk penanaman modal asing (PMA) maupun penanaman modal dalam negeri (PMDN) mempunyai pengaruh positif terhadap pertumbuhan ekonomi di Indonesia (Sodik dan Nuryadin, 2005). Penelitian lain yang dilakukan oleh Yudisthira dan Budhiasa (2013) dengan tujuan penelitian untuk mengetahui pengaruh konsumsi, investasi, dan inflasi terhadap Produk Domestik Bruto (PDB). Penelitian ini dilakukan di Indonesia dengan data kuartalan tahun 2000 sampai dengan 2012. Teknis analisis yang digunakan adalah dengan Two Stage Least Square (TSLS). Berdasarkan hasil analisis, ditemukan bahwa konsumsi, investasi, berpengaruh positif dan signifikan terhadap model PDB. Penelitian lainnya adalah penelitian dari Silvia et al. (2013) yang menyimpulkan bahwa variabel konsumsi, investasi dan net ekspor mempunyai pengaruh signifikan terhadap pertumbuhan ekonomi di Indonesia. Penelitian sejenis lainnya menyimpulkan bahwa konsumsi, investasi dan pengeluaran pemerintah berdampak positif dan signifikan terhadap pertumbuhan ekonomi di Indonesia (Ernita et al., 2013). Suhendar dan Anwar (2014) dalam penelitiannya menyebutkan bahwa variabelvariabel yang mempengaruhi pertumbuhan ekonomi di Indonesia adalah investasi swasta dan pemerintah, sumber daya manusia, dan jumlah tenaga kerja.

Investasi domestik maupun investasi asing berkontribusi besar terhadap pertumbuhan ekonomi negara-negara berkembang di Asia (Phetsavong dan Ichihashi, 2012) maupun di negara-negara berkembang lainnya (Waheed, 2004). Penelitian lainnya yang membahas bagaimana hubungan antara investasi dan pertumbuhan ekonomi di negara-negara berkembang adalah penelitian Khan (1996) yang menunjukkan bahwa pengaruh investasi terhadap pertumbuhan ekonomi di 95 negara berkembang yang dijadikan objek penelitian berbeda-beda antara negara satu dengan lainnya. Bagaimana investasi dapat berpengaruh positif terhadap perkembangan ekonomi suatu negara ditentukan juga oleh seberapa siap negara tujuan investasi tersebut mempunyai kemampuan yang cukup untuk menyerap perubahan teknologi yang diperlukan (Borensztein et al., 1998).

\section{Inflasi}

Hasil pengujian untuk variabel inflasimenunjukan bahwa inflasi secara nominal tidak signifikan dan berpengaruh negatif terhadap pertumbuhan ekonomi. Nilai koefisien regresi untuk variabel tingkat inflasi sebesar -0,094. Tanda negatif mengindikasikan bahwa pengaruh tingkat inflasi terhadap pertumbuhan ekonomi adalah negatif. Arti dari nilai koefisien regresi tersebut jika variabel independen lain nilainya tetap dan variabel tingkat inflasi (X2) mengalami kenaikan sebesar $1 \%$ maka pertumbuhan ekonomi (Y) akan mengalami penurunan sebesar 0,094\%.

Laju inflasi yang tinggi memiliki dampak negatif bagi perekonomian. Inflasi yang tinggi akan mengganggu mobilisasi dana dan stabilitas perekonomian. Pada prospek pembangunan ekonomi jangka panjang akan memburuk jika terjadi inflasi yang tinggi (hyperinflation) dan tidak terkendali. Inflasi yang tinggi akan menyebabkan harga barangbarang Indonesia relatif menjadi lebih mahal dibandingkan negara lain. Peningkatan harga ini akan menyebabkan barang-barang dalam negeri kalah bersaing dengan barang-barang luar negeri. Kondisi ini akan mengakibatkan penurunan ekspor kita ke luar negeri, Di lain pihak, peningkatan harga barang produksi domestik akan menyebabkan harga barang dan jasa impor relatif menjadi lebih murah, maka impor akan meningkat. Dengan demikian arus modal luar negeri akan lebih banyak dibandingkan dengan arus modal yang masuk ke dalam negeri. Keadaan seperti ini akan mengakibatkan terjadinya defisit neraca pembayaran dan kemerosotan nilai mata uang dalam negeri. 
Tingginya inflasi yang menyebabkan tingginya harga barang dan jasa. Hal ini dapat menurunkan daya beli masyarakat dan berakibat pada berkurangnya tingkat kesejahteraan masyarakat. Turunnya kesejahteraan masyarakat akan berimbas pada turunnya permintaan agregat dan pada akhirnya akan berdampak pada lesunya sektor produksi. Jika hal ini terus terjadi, maka akan menyebabkan roda perekonomian mengalami penuruan atau dengan kata lain perekonomian akan mengalami perlambatan, yang ditandai dengan menurunnya laju pertumbuhan ekonomi.

Hasil penelitian ini sejalan dengan penelitian yang dilakukan oleh Silvia et al. (2013) dan penelitian Antoni (2012) bahwa inflasi memiliki pengaruh negatif terhadap pertumbuhan ekonomi. Jika inflasi meningkat maka akan memperlambat laju pertumbuhan ekonomi, sebaliknya jika inflasi menurun maka akan berdampak terhadap peningkatan pertumbuhan ekonomi di Indonesia.

Penelitian lainnya yang memperlihatkan bahwa inflasi berpengaruh negatif dan signifikan terhadap pertumbuhan ekonomi suatu negara diperlihatkan oleh penelitian Jayathileke dan Rathnayake (2013), Muritala (2011) dan Chaturvedi et al. (2009). Di Pakistan inflasi yang tinggi (di atas 6\%) memberikan dampak negatif terhadap pertumbuhan negara tersebut, sedangkan inflasi di bawah 6\% memperikan dampak positif walaupun tidak cukup signifikan pengaruhnya terhadap pertumbuhan ekonomi Pakistan (Nasir dan Saima, 2010).

\section{KESIMPULAN}

Investasi memiliki pengaruh yang positif terhadap pertumbuhan ekonomi, yang menunjukkan bahwa jika sektor investasi mengalami peningkatan maka pertumbuhan ekonomi juga mengalami kenaikan. Dengan investasi akan meningkatkan kapasitas produksi yang pada akhirnya berujung pada pembukaan lapangan kerja baru, yang pada tahap selanjutnya akan mendorong pertumbuhan ekonomi. Di samping itu, adanya peningkatan investasi memungkinkan terjadinya transfer teknologi dan ilmu pengetahuan.

Inflasi siginifikan berpengaruh negatif terhadap pertumbuhan ekonomi. Hal ini menunjukkan bahwa ketika terjadi kenaikan pada tingkat inflasi maka pertumbuhan ekonomi akan mengalami penurunan, namun tidak signifikan. Laju inflasi yang tinggi memiliki dampak negatif bagi perekonomian. Inflasi yang tinggi akan mengganggu mobilisasi dana dan stabilitas perekonomian. Oleh karena itu peran pemerintah diperlukan dalam rangka menjaga tingkat inflasi berada pada tingkat yang cukup rendah dan stabilitasnya terjaga.

\section{DAFTAR PUSTAKA}

Antoni. 2012. Kointegrasi Antara Inflasi dan Pertumbuhan Ekonomi di Indonesia. Jurnal Ekonomi Bisnis dan Koperasi, 12(2).

Borensztein, Eduardo et al. 1998. How Does Foreign Direct Investment Affect Economic Growth. Journal of International Economics, 45: 115-135.

Chaturvedi, Vaibhav et al. 2009. Inter-Realtionship Between Economic Growth, Savings and Inflation in Asia. Journal of International Economic Studies, (23): 1-22.

Effendi, Nury \& Soemantri M., Femmy. 2003. Foreign Direct Investment And Regional Economic Growth In Indonesia: A Panel Data Study. Working Paper in Economics and Development Studies, Juli(200305).

Ernita, Dewi et al. 2013. Analisis Pertumbuhan Ekonomi, Investasi dan Konsumsi di Indoensia. Jurnal Kajian Ekonomi, I(02): 176-193.

Jayathileke, Pradana M. Bandula \& Rathnayake, Rathnayaka M. Kapila Tharanga. 2013. Testing the Link between Inflation and Economic Growth: Evidence from Asia. Modern Economy, 4: 87-92.

Khan, Mohsin S. 1996. Government Investment and Economic Growth in the Developing World. The Pakistan Development Review, 35(4): 419-439.

Muritala, Taiwo. 2011. Investment, Inflation and Economic Growth: Empirical Evidence from Nigeria. Research Journal of Finance and Accounting, 2(5): 68-76.

Nasir, Iqbal \& Saima, Nawaz. 2010. Investment, Inflation and Economic Growth Nexus. MPRA Paper, December(27163).

Nunnenkamp, Peter \& Spatz, Julius. 2004. FDI and Economic Growth in Developing Economies: How Relevant are Host-Economy and Industry Characteristics. Transnational Corporations, 13(3): 52-86. 
Phetsavong, Kongphet \& Ichihashi, Masaru. 2012. The Impact of Public and Private Investment on Economic Growth: Evidence from Developing Asian Countries. IDEC Discussion Paper Hiroshima University, 1-21.

Silvia, Engla Desnimet al.2013.Analisis Pertumbuhan Ekonomi, Investasi dan Inflasi di Indonesia. Jurnal Kajian Ekonomi, I(02): 224-243.

Sodik, Jamzani \& Nuryadin, Didi. 2005. Investasi dan Pertumbuhan Ekonomi Regional (Studi Kasus pada 26 Propinsi di Indonesia, Pra dan Pasac Otonomi. Jurnal Ekonomi Pembangunan, 10(2): 157-170.
Suhendar, Indra \& Anwar, Cep Jandi. 2014. Determinants of Private Investment and The Effects on Economic Growth in Indonesia. GSTF International Journal on Business Review (GBR), 3(3).

Waheed, Abdul. 2004. Foreign Capital Inflow and Economic Growth of Developing Countries: A Critical Selected Empirical Studies. Journal of Economic Cooperation, 25(1): 1-36.

Yudisthira, I Made \& Budhiasa, I Gede Sujana. 2013. Analisis Pengaruh Konsumsi, Investasi, dan Inflasi Terhadap Produk Domestik Bruto di Indonesia Tahun 2000-2012. E-Jurnal EP Unud, 2(11): 492-501. 